\title{
The Effect of a 8 Week-Explosive Power Training on Some Performance Parameters of Students who Studying in Sports High School
}

\author{
Dede Baştürk $^{1} \&$ Alper Tunga Peker ${ }^{2}$ \\ ${ }^{1}$ Kırşehir Ahi Evran University, School of Physical Education, Kırşehir, Turkey \\ ${ }^{2}$ Ağrı İbrahim Çeçen University, School of Physical Education, Ağrı, Turkey \\ Correspondence: Dede Baştürk, Kırşehir Ahi Evran University, School of Physical Education, Kırşehir, Turkey. \\ E-mail: dbasturk@ahievran.edu.tr
}

Received: June 2, 2019 Accepted: September 25, 2019 Online Published: October 25, 2019

doi:10.5539/hes.v9n4p155 URL: https://doi.org/10.5539/hes.v9n4p155

\begin{abstract}
Aim of this study is to analyze the effect of a 8 week-explosive power training on some performance parameters of students who studying in sports high school. A total of 101 healthy male canoist students who studying in sports high school volunteered to participate in this study. students were randomly divided into two groups and test $(\mathrm{N}=51)$ and control $(\mathrm{N}=50)$ groups were formed. Explosive power trainings were applied to test group during 8 weeks as 30-minute trainings for 3 days a week in addition to canoe training and control group continued only canoe training. All data were obtained twice as pre-test and post-test before and after training. Four line sprint test, standing long jump test and $20 \mathrm{~m}$ sprint test were used to determine performances of the subjects When results of the study are examined, it is seen that explosive power trainings applied during 8 weeks had statistically significant effects in favor of the post-tests for $20 \mathrm{~m}$ sprint, sprint-agility and standing long jump performances pre-test and post-test results $(\mathrm{P}<0.05)$. In addition, when post-test results of test and control group were compared, it was found that test group's $20 \mathrm{~m}$ sprint, sprint-agility and standing long jump performances post-test results showed statistically more significant improvement than control group's post-test results $(\mathrm{P}<0.05)$. These results confirm our expectations before the research. Consequently, it can be thought that explosive power trainings applied have positive effects on $20 \mathrm{~m}$ sprint, sprint-agility and standing long jump performances.
\end{abstract}

Keywords: students, explosive training, sprint, sprint-agility, standing long jump

\section{Introduction}

Ability to develop a performance requiring high power in sports is often a determinant of athletic success (Stone, 1993). In fact, it is believed that ability to develop high power is one of the most important factors, especially in sporting performances including jump and sprint (Mcbridge, Triplett-Mcbridge, Davie \& Newton, 1999). Use of resistance or power training methods with explosive exercise components in trainings may improve athletes' ability to produce high power. Explosive exercises are usually applied at almost maximal or nearly maximal explosive power intensities that improve an athlete's ability to produce high rates of acceleration (Schmidtbleicher, 1993) The highest recorded explosive power development rates were seen in male power athletes who did explosive exercises at varying loads during trainings (Haff et al., 1997; Hakkinen \& Myllyla, 1990). It is seen that explosive exercises tend to improve an athlete's ability to develop high level of explosive power (Hakkinen, Mero \& Kauhanen, 1989; Hakkinen \& Myllyla, 1990; Zatsiorsky, 1995; Haff et al., 1997). Contrary to this, low intensity exercises tend to disrupt the ability to develop explosive power (Viitasalo, 1984; Hakkinen, Komi \& Alen, 1985; Hakkinen \& Myllyla, 1990; Zatsiorsky, 1995). Almost every exercise can be applied explosively depending on the use of training intensity. Various researches and review articles have reported valid arguments for the use of explosive exercises. Such exercises are determined by the use by athletes participating in power and strength sports or by the movements requiring high power and speed. (Garhammer, 1982; Sale, 1988; Deschenes, 1989; Hakkinen et al., 1989; Stone, 1990; Garhammer, 1993). We usually describe exercises that are done along with determined movement sequence and require maximal or nearly maximal power development as explosive exercises. Such exercises focus on movement acceleration resulting in maximal or nearly maximal movement speed at a specific resistance and are determined by beginning of a fast power 
development. Explosive exercise type used in training program will then affect changeable response of the athlete and will ultimately affect his sports performance. Improvements in sports performance with the use of explosive exercises may partially depend on movement and speed forms required by the sports and the athlete's training status (Haff, Whitley \& Potteiger, 2001).

Aim of this study is to analyze effect of 8 week-explosive power trainings on sprint-agility, 20m sprint and standing long jump performances by using all scientific information mentioned above as a source of motivation. We hope that the short term high intensity explosive power trainings applied by us in the research will have a positive effect on the performances relating to the components mentioned above, because information in the literature has led us to think in this direction.

\section{Method}

\subsection{Experimental Approach to the Problem}

This investigation involved sectional design to evaluate The Effect of 8 Week-Explosive Strength Training on Sprint-Agility, 20m Sprint and Long Jump. A total of 101 healthy male canoist students volunteered to participate in this study.

The four line sprint test, standing long jump test and $20 \mathrm{~m}$ sprint test, which used by previous authors, were used for subjects (Taskin, 2009; Lockie et al., 2014; Chaabene et al., 2019; Scanlan et al., 2019).

\subsection{Subjects}

101 canoist students who studying in sports high school volunteered to participate in this research. All risks relating to the research were explained to them before the study and necessary information was provided. students were randomly divided into two groups and test $(\mathrm{N}=51)$ and control $(\mathrm{N}=50)$ groups were formed. Explosive power trainings were applied to test group during 8 weeks as 30-minute trainings for 3 days a week in addition to canoe training and control group continued only canoe training. All data were obtained twice as pre-test and post-test before and after training.

\subsection{Measurements}

\subsubsection{Standing Long Jump Test}

To assess horizontal expression of power players performed a bilateral, standing long jump from a stationary position. In a parallel stance with toes placed behind the starting line, players were instructed to jump as far as possible while swinging their arms. The total distance traveled was determined with a measuring tape and taken from the starting line to the heel of the nearest foot to the nearest $0.1 \mathrm{~cm}$. Jump attempts where players lost balance on landing and did not maintain a stationary position were disregarded and reattempted (Lockie et al., 2014; Scanlan et al., 2019)

\subsubsection{0m Sprint Test}

For this test, a 20 meters of line was formed with starting and finish points and two photocells were placed on the starting point and finish points of the line. Subject was ready just behind the starting point, he was told that he could go at any time he felt ready and was asked to run at the highest possible speed until he passed by the photocell on the finish point. When subject felt ready, he started and run at the highest possible speed and finished running by passing through the photocell on the finish line and 20-meter running time was recorded by the photocell. It was applied twice for each subject and the best time was accepted as the score (Chaabene et al., 2019).

\subsubsection{Four Line Sprint-Agility Test}

The 4-line sprint test allows assessment of sprint-agility, or ability to change direction quickly. The player lies on the ground behind the starting line (A). On the signal "Ready-Go," he runs $10 \mathrm{~m}$ to line B and touches this with his foot. Then he turns, runs from line B $20 \mathrm{~m}$ back to line $\mathrm{C}$ and touches this line. He then turns again, runs $10 \mathrm{mfrom}$ line $\mathrm{C}$ to line $\mathrm{A}$ and touches this line, turns, and then runs $30 \mathrm{~m}$ to the finish line between 2 flag posts. The touching of the lines should be checked. Using a handheld stopwatch, the examiner measures the time between the "Go" signal and crossing the finish line in units of 0.1 seconds (Rösch et al., 2000; Taskin, 2009). 


\subsection{Training Program Applied to the Subjects}

\begin{tabular}{|c|c|c|c|}
\hline Weeks & Monday & Wednesday & Friday \\
\hline 1st Week & $\begin{array}{l}\text { Squat jump } 15 \text { sec } X 3 \text { repetitions, } \\
50 \mathrm{sec} \text { rest between repetitions } \\
\text { Standing knee lift } 20 \mathrm{sec} \times 3 \\
\text { repetitions, } 50 \text { sec rest between } \\
\text { repetitions } \\
10 \text { sec sprint, } 3 \text { min running by } \\
\text { walking } 40 \mathrm{sec}\end{array}$ & $\begin{array}{l}\text { After one foot crosswise jump once to the } \\
\text { right and once to the left total } 4 \text { jumps ( } 2 \\
\text { right- } 2 \text { left), } 10 \text { meters forward, } 10 \text { meters } \\
\text { backward sprint X } 4 \text { repetitions, } 50 \text { sec rest } \\
\text { between repetitions. } \\
10 \text { sec sprint, } 3 \text { min running by walking } 40 \\
\text { sec }\end{array}$ & $\begin{array}{l}15 \mathrm{sec} \text { jumping over } 40 \mathrm{~cm} \text { of barrier } \mathrm{X} 3 \\
\text { repetitions, } 50 \mathrm{sec} \text { rest between repetitions } \\
\text { Twice double foot jump forward, as soon } \\
\text { as contacting with the ground after } 2 \\
\text { jumps, } 30 \text { meters sprint X } 4 \text { repetitions, } 50 \\
\text { sec rest between repetitions }\end{array}$ \\
\hline 2nd Week & $\begin{array}{l}15 \text { sec jumping over } 40 \mathrm{~cm} \text { of } \\
\text { barrier X } 3 \text { repetitions, } 50 \mathrm{sec} \text { rest } \\
\text { between repetitions } \\
\text { Twice double foot jump forward, as } \\
\text { soon as contacting with the ground } \\
\text { after } 2 \text { jumps, } 30 \text { meters sprint } X 4 \\
\text { repetitions, } 50 \mathrm{sec} \text { rest between } \\
\text { repetitions }\end{array}$ & $\begin{array}{l}\text { Squat jump } 15 \mathrm{sec} X 3 \text { repetitions, } 50 \mathrm{sec} \\
\text { rest between repetitions } \\
\text { Standing knee lift } 20 \mathrm{sec} \text { X } 3 \text { repetitions, } \\
50 \mathrm{sec} \text { rest between repetitions } \\
10 \mathrm{sec} \text { sprint, } 3 \text { min running by walking } 40 \\
\mathrm{sec}\end{array}$ & $\begin{array}{l}\text { After one foot crosswise jump once to the } \\
\text { right and once to the left total } 4 \text { jumps ( } 2 \\
\text { right- } 2 \text { left), } 10 \text { meters forward, } 10 \text { meters } \\
\text { backward sprint } X 4 \text { repetitions, } 50 \text { sec rest } \\
\text { between repetitions. } \\
10 \text { sec sprint, } 3 \text { min running by walking } 40 \\
\text { sec }\end{array}$ \\
\hline 3rd Week & $\begin{array}{l}\text { Squat jump } 20 \text { sec } X 3 \text { repetitions, } \\
50 \text { sec rest between repetitions } \\
\text { Standing knee lift } 20 \mathrm{sec} \times 3 \\
\text { repetitions, } 50 \text { sec rest between } \\
\text { repetitions } \\
15 \text { sec sprint, } 3 \text { min running by } \\
\text { walking } 40 \mathrm{sec}\end{array}$ & $\begin{array}{l}20 \mathrm{sec} \text { jumping over } 40 \mathrm{~cm} \text { of barrier X } 3 \\
\text { repetitions, } 50 \mathrm{sec} \text { rest between repetitions } \\
\text { Twice double foot jump forward, as soon } \\
\text { as contacting with the ground after } 2 \\
\text { jumps, } 30 \text { meters sprint X } 4 \text { repetitions, } 50 \\
\text { sec rest between repetitions }\end{array}$ & $\begin{array}{l}\text { After one foot crosswise jump once to the } \\
\text { right and once to the left total } 4 \text { jumps ( } 2 \\
\text { right- } 2 \text { left), } 10 \text { meters forward, } 10 \text { meters } \\
\text { backward sprint } X 4 \text { repetitions, } 50 \text { sec rest } \\
\text { between repetitions. } \\
15 \text { sec sprint, } 3 \text { min running by walking } 40 \\
\text { sec }\end{array}$ \\
\hline 4th Week & $\begin{array}{l}20 \mathrm{sec} \text { jumping over } 40 \mathrm{~cm} \text { of } \\
\text { barrier X } 3 \text { repetitions, } 50 \mathrm{sec} \text { rest } \\
\text { between repetitions } \\
\text { Twice double foot jump forward, as } \\
\text { soon as contacting with the ground } \\
\text { after } 2 \text { jumps, } 30 \text { meters sprint } X 4 \\
\text { repetitions, } 50 \text { sec rest between } \\
\text { repetitions }\end{array}$ & $\begin{array}{l}\text { After one foot crosswise jump once to the } \\
\text { right and once to the left total } 4 \text { jumps ( } 2 \\
\text { right- } 2 \text { left), } 10 \text { meters forward, } 10 \text { meters } \\
\text { backward sprint } X 4 \text { repetitions, } 50 \text { sec rest } \\
\text { between repetitions. } \\
15 \text { sec sprint, } 3 \text { min running by walking } 40 \\
\text { sec }\end{array}$ & $\begin{array}{l}\text { Squat jump } 20 \mathrm{sec} X 3 \text { repetitions, } 50 \mathrm{sec} \\
\text { rest between repetitions } \\
\text { Standing knee lift } 20 \mathrm{sec} X 3 \text { repetitions, } \\
50 \mathrm{sec} \text { rest between repetitions } \\
15 \mathrm{sec} \text { sprint, } 3 \text { min running by walking } 40 \\
\text { sec }\end{array}$ \\
\hline
\end{tabular}

Note: Prior to each training, general warm up was performed for 10 minutes. All of the works were performed at $100 \%$ tempo and rests were completed by stretching for 50 seconds. Same program was applied for 5 th ,6th ,7th and 8 th weeks, only rest intervals were reduced by 15 seconds.

\subsection{Statistical Analysis}

SPSS 23.00 program was used to analyze data and find calculated values. By using Kolmogorov-Smirnov test, it was determined that data distributed normally. Two paired samples T-test was used for intra-group comparisons and independent samples T-test was used for inter-group comparisons. Data were presented as mean and standard deviation and error level was taken as 0.05 in this study. 


\section{Findings}

Table1. Presenting data of the subjects as descriptive statistics

\begin{tabular}{lllll}
\hline Groups & Variables & N & Mean & SD \\
\hline Test & Height (m) & 51 & 167,49 & 7,38 \\
& Weight (kg) & 51 & 57,82 & 11,57 \\
& Age (year) & 51 & 15,08 & 1,09 \\
& 20 meter sprint - pre-test (s) & 51 & 3,9600 &, 30 \\
& Long jump - pre-test (cm) & 51 & 170,5412 & 22,80 \\
& Sprint-Agility - pre-test (s) & 51 & 17,86 & 1,53 \\
& 20 meter sprint - post-test (s) & 51 & 3,5914 &, 27 \\
& Long jump - post-test (cm) & 51 & 175,2890 & 22,27 \\
& Sprint-Agility - post-test (s) & 51 & 16,88 & 1,52 \\
\hline Control & Height (m) & 50 & 166,88 & 7,35 \\
& Weight (kg) & 50 & 56,48 & 8,46 \\
& Age (year) & 50 & 15,34 & 1,08 \\
& 20 meter sprint - pre-test (s) & 50 & 3,9422 &, 28 \\
& Long jump - pre-test (cm) & 50 & 169,3920 & 24,03 \\
& Sprint-Agility - pre-test (s) & 50 & 17,55 & 1,33 \\
& 20 meter sprint - post-test (s) & 50 & 3,9378 &, 31 \\
& Long jump - post-test (cm) & 50 & 164,3606 & 19,07 \\
& Sprint-Agility - post-test (s) & 50 & 17,68 & 1,50 \\
\hline
\end{tabular}

Table 2. Comparing pre-test and post-test results in terms of test and control groups.

\begin{tabular}{llllllll}
\hline Variables & Groups & $\mathbf{N}$ & Mean & Mean Difference & SD & T & P \\
\hline 20 meter sprint - & Test & 51 & 3,96 & 0,01780 & 0,30 & 0,311 & 0,756 \\
pre-test (s) & Control & 50 & 3,94 & & 0,28 & & \\
Long jump - & Test & 51 & 170,54 & 1,14918 & 22,80 & 0,247 & 0,806 \\
pre-test (cm) & Control & 50 & 169,39 & & 24,03 & & \\
Sprint-Agility - & Test & 51 & 17,86 & 0,20582 & 1,53 & 1,071 & 0,287 \\
pre-test (s) & Control & 50 & 17,65 & & 1,33 & & \\
20 meter sprint - & Test & 51 & 3,59 & $-0,34643$ & 0,27 & $-6,044$ & $0,000^{*}$ \\
post-test (s) & Control & 50 & 3,94 & & 0,31 & & \\
Long jump - & Test & 51 & 175,29 & 10,92842 & 22,27 & 2,647 & $0,009^{*}$ \\
post-test (cm) & Control & 50 & 164,36 & & 19,07 & & \\
Sprint-Agility - & Test & 51 & 17,34 & $-0,31443$ & 1,52 & $-3,286$ & $0,001^{*}$ \\
post-test (s) & Control & 50 & 17,68 & & 1,50 & & \\
\hline
\end{tabular}

As shown in Table 2, no statistically significant difference was found in the comparison of test and control groups in terms of pre-test results. On the other hand, it was found in comparison of test and control groups in terms of post-test results that there were significant differences for $20 \mathrm{~m}$ sprint, sprint-agility and long jump performances in favor of control group $(\mathrm{P}<0.05)$. 
Table 3. Comparison of pre-test and post-test results of test group

\begin{tabular}{lllllll}
\hline Groups & Variables & Mean & Mean Difference & SD & T & P \\
\hline Test (N=51) & $\begin{array}{l}\text { 20 meter sprint - } \\
\text { pre-test (s) }\end{array}$ & 3,9600 &, 36863 &, 29921 & 22,687 & $0,000^{*}$ \\
& $\begin{array}{l}\text { 20 meter sprint - } \\
\text { posttest (s) }\end{array}$ & 3,5914 & &, 28031 & & \\
& $\begin{array}{l}\text { Long jump - } \\
\text { pre-test (cm) }\end{array}$ & 170,5412 & $-5,74784$ & 22,79549 & $-8,810$ & $0,000^{*}$ \\
& $\begin{array}{l}\text { Long jump - } \\
\text { post-test (cm) }\end{array}$ & 176,2890 & & 22,26490 & & \\
$\begin{array}{l}\text { Sprint-Agility - } \\
\text { pre-test (s) } \\
\begin{array}{l}\text { Sprint-Agility - } \\
\text { post-test (s) }\end{array}\end{array}$ & 17,86 &, 51745 & 1,52621 & 10,921 & $0,000^{*}$ \\
& & & 1,52729 & & \\
\hline
\end{tabular}

As shown in Table 3, significant differences were determined in favor of post-tests in comparison between pre-test and post-test results of test group's $20 \mathrm{~m}$ sprint, standing long jump and sprint-agility performances (P $<0.05)$.

Table 4. Comparison of pre-test and post-test results of control group

\begin{tabular}{lllllll}
\hline Groups & Variables & Mean & Mean Difference & SD & T & P \\
\hline Control (N=50) & 20 meter sprint - pre-test (s) & 3,9422 &, 00440 &, 27463 &, 085 & 0,933 \\
& 20 meter sprint - post-test (s) & 3,9378 & &, 29566 & & \\
& Long jump - pre-test (cm) & 169,3920 & 3,03140 & 24,03369 & 1,755 & 0,085 \\
& Long jump - post-test (cm) & 166,3606 & & 19,07374 & & \\
& Sprint-Agility - pre-test (s) & 17,65 &,- 0264 & 1,33424 & $-3,890$ & 0,208 \\
& Sprint-Agility - post-test (s) & 17,68 & & 1,49800 & & \\
\hline
\end{tabular}

As shown in Table 4, no significant difference was determined in comparison between pre-test and post-test results of control group's $20 \mathrm{~m}$ sprint, standing long jump and sprint-agility performances.

\section{Discussion}

Factors including power and muscle strength production, several factors such as (use of motor unit and modes of activation, speed coding, synchronization, neural inhibition, cross-sectional area of muscle, motor unit type) can be classified. Effect of explosive exercises as a training tool may be related to their ability to affect these factors. When especially these factors are examined, body's ability to use motor units or to stimulate speed coding mechanism has critical importance to understand effect of explosive trainings on sports performance. In addition, hypertrophic response to explosive exercises may add further evidence to effect of explosive trainings as a training style (Stone, 1990; Haff et al., 2001).

When results of the study are examined, it is seen that explosive power trainings applied during 8 weeks had statistically significant effects in favor of the post-tests for $20 \mathrm{~m}$ sprint, sprint-agility and standing long jump performances pre-test and post-test results $(\mathrm{P}<0.05)$. In addition, when post-test results of test and control group were compared, it was found that test group's $20 \mathrm{~m}$ sprint, sprint-agility and standing long jump performances post-test results showed statistically more significant improvement than control group's post-test results $(\mathrm{P}<0.05)$. These results confirm our expectations before the research. Consequently, it can be thought that explosive power trainings applied have positive effects on $20 \mathrm{~m}$ sprint, sprint-agility and standing long jump performances.

In a study conducted by Santos and Janeira (2008); it was seen that post-test results of test group to which complex resistance and plyometric quick power trainings were applied for 10 weeks, relating to activities requiring explosive power such as squat jump, counter movement jump, deep jump, medicine ball throwing were significantly higher than post-test results of control group. In addition, when test group's pre-test and post-test results were compared, significant improvements were determined in favor of post-test results.

In a recent study, it was seen that plyometric training group's and contrast strength training group's squat jump and counter movement jump performances post-test results were significantly higher than control group's post-test results. On the other hand, it was found that plyometric training group's agility performance post-test 
results were significantly higher than control group's agility performance post-test results (Hammami, Gaamouri, Shephard \& Chelly, 2019).

In another study conducted on children. it was determined that 3 different explosive strength training had statistically significant effects on agility performance measured by using 3 different methods (Keller, Koob, Corak \& Born, 2018).

Again in one of the recent studies; effect of explosive power related plyometric trainings on some performance components of young female handball players was examined. According to the results of the research, explosive power trainings significantly improved 5, 10,20 m sprint performance and agility performance of test group (Chaabene et al., 2019).

Consequently, when we examine recent studies in the literature, results of the studies conducted support results of our study. If an evaluation is made considering the results in the literature and results of this study; it is thought that short term high intensity explosive power trainings can improve performance components requiring explosive power by effecting factors including power and muscle strength production. It is thought that explosive power trainings used in this study have positive effects on explosive power and can be used in trainings for athletes engaging in sports branches including components such as agility, quickness, acceleration, pace, speed, explosive power and jump.

\section{References}

Chaabene, H., Negra, Y., Moran, J., Prieske, O., Sammoud, S., Ramirez-Campillo, R., \& Granacher, U. (2019). Plyometric Training Improves Not Only Measures of Linear Speed, Power, and Change-of-Direction Speed But Also Repeated Sprint Ability in Female Young Handball Players. Journal of strength and conditioning research. https://doi.org/10.1519/JSC.0000000000003128

Deschenes, M. (1989). Short review: Rate coding and motor unit recruitment patterns. J. Appl. Sports Sci. Rev., 3(2), 34-39. https://doi.org/10.1519/00124278-198905000-00003

Garhammer, J. (1982). Free weight equipment for the development of athletic strength and power. Natl. Strength Cond. Assoc. J., 3(6), 24-26. https://doi.org/10.1519/0199-610X(1981)003<0024:FWEFTD>2.3.CO;2

Garhammer, J. (1991). A Comparison of maximal power outputs between elite male and Female weightlifters in competition. Int. J. Sports Biomech, 7(1), 3-11. https://doi.org/10.1123/ijsb.7.1.3

Haff, G. G., Whitley, A., \& Potteiger, J. A. (2001). A brief review: Explosive exercises and sports performance. Strength and Conditioning Journal, 23(3), 13-25. https://doi.org/10.1519/00126548-200106000-00003

Haff, G., Stone, M., O’Bryant, H. S., Harman, E., Dinan, C., Johnson, R., \& Han, K. (1997). Force-time dependent characteristics of dynamic and isometric muscle actions. J. Strength Cond. Res., 11(4), 269-272. https://doi.org/10.1519/00124278-199711000-00014

Häkkinen, K., \& Myllylä, E. (1990). Acute effects of muscle fatigue and recovery on force production and relaxation in endurance, power, and Strength athletes. J. Sports Med. Phys. Fitness, 30, 5-12. Retrieved from https://europepmc.org/abstract/med/2195236

Häkkinen, K., Komi, P. V., \& Alen, M. (1985). Isometric force and relaxation-time, electromyographic and muscle fiber characteristics of leg extensor muscles. Acta Physiol. Scand, 125, 587-600. https://doi.org/10.1111/j.1748-1716.1985.tb07760.x

Häkkinen, K., Mero, A., \& Kauhanen, H. (1989). Specificity of endurance, sprint, and Strength training on physical performance capacity in young athletes. J. Sports Med., 29, 23-35. Retrieved from https://europepmc.org/abstract/med/2770265

Hammami, M., Gaamouri, N., Shephard, R. J., \& Chelly, M. S. (2019). Effects of Contrast Strength vs. Plyometric Training on Lower-Limb Explosive Performance, Ability to Change Direction and Neuromuscular Adaptation in Soccer Players. The Journal of Strength \& Conditioning Research, 33(8), 2094-2103. https://doi.org/10.1519/JSC.0000000000002425

Keller, S., Koob, A., Corak, D., \& Born, D. P. (2018). How to Improve Change-of-Direction Speed in Junior Team Sport Athletes-Horizontal, Vertical, Maximal, or Explosive Strength Training?. Journal of strength and conditioning research. https://doi.org/10.1519/JSC.0000000000002814

Lockie, R. G., Callaghan, S. J., Berry, S. P., Cooke, E. R., Jordan, C. A., Luczo, T. M., \& Jeffriess, M. D. (2014). Relationship between unilateral jumping ability and asymmetry on multidirectional speed in team-sport 
athletes. The Journal of Strength \& Conditioning Research, 28(12), 3557-3566. https://doi.org/10.1519/JSC.0000000000000588

McBride, J. M., Triplett-McBride, T., Davie, A., \& Newton, R. U. (1999). A comparison of strength and power characteristics between power lifters, Olympic lifters and sprinters. J. Strength Cond. Res., 13(1), 58-66. https://doi.org/10.1519/00124278-199902000-00011

Rösch, D., Hodgson, R., Peterson, L., Baumann, T. G., Junge, A., Chomiak, J., \& Dvorak, J. (2000). Assessment and evaluation of football performance. Am J Sports Med, 28(5), 29-39. https://doi.org/10.1177/28.suppl_5.s-29

Sale, D. G. (1988). Neural adaptations to resistance training. Med. Sci. Sports Exerc., 20(Suppl.), S135-S145. https://doi.org/10.1249/00005768-198810001-00009

Santos, E. J., \& Janeira, M. A. (2008). Effects of complex training on explosive strength in adolescent male basketball players. The Journal of Strength \& Conditioning Research, 22(3), 903-909. https://doi.org/10.1519/JSC.0b013e31816a59f2

Scanlan, A. T., Wen, N., Pyne, D. B., Stojanović, E., Milanović, Z., Conte, D., \& Dalbo, V. J. (2019). Power-Related Determinants of Modified Agility T-test Performance in Male Adolescent Basketball Players. Journal of strength and conditioning research. https://doi.org/10.1519/JSC.0000000000003131

Schmidtbleicher, D. (1993). Training for power events. In: Strength and Power in Sport. P.V. Komi, ed. London: Blackwell Scientific Publications, pp. 381-395.

Stone, M. H. (1990). Muscle conditioning and muscle injuries. Med. Sci. Sports Exerc., 22(4), 457-462. https://doi.org/10.1249/00005768-199008000-00007

Stone, M. H. (1993). Position paper and literature review: Explosive exercises and training. Natl. Strength Cond. Assoc. J., 15(3), 7, 9-15. https://doi.org/10.1519/0744-0049(1993)015<0007:EEAT>2.3.CO;2

Taskin, H. (2009). Effect of circuit training on the sprint-agility and anaerobic endurance. The Journal of Strength \& Conditioning Research, 23(6), 1803-1810. https://doi.org/10.1519/JSC.0b013e3181b3dfc0

Viitasalo, J. T., \& Aura, O. (1984). Seasonal fluctuations of force production in high jumpers. Can. J. Appl. Sports Sci., 9, 209-213.. https://europepmc.org/abstract/med/6525754

Zatsiorsky, V. M. (1995). Science and Practice of Strength Training. Champaign, IL: Human Kinetics.

\section{Copyrights}

Copyright for this article is retained by the author(s), with first publication rights granted to the journal.

This is an open-access article distributed under the terms and conditions of the Creative Commons Attribution license (http://creativecommons.org/licenses/by/4.0/). 